\title{
Limits and prospects of photovoltaic covers in Mediterranean greenhouses
}

\author{
Alvaro Marucci, ${ }^{1}$ Adolfo Gusman, ${ }^{2}$ Barbara Pagniello, ${ }^{1}$ Andrea Cappuccini ${ }^{1}$ \\ ${ }^{1}$ Department of Agriculture, Forests, Nature and Energy (D.A.F.N.E.), University of Tuscia, \\ Viterbo; ${ }^{2}$ Freelance, Viterbo, Italy
}

\begin{abstract}
The use of plastic film coverings has made a significant contribution to the development of greenhouses in Italy and to a new generation of greenhouses that differ from those of Central and Northern Europe: the so called Mediterranean Greenhouse. This is a simple structure with cheap coverings and emergency artificial heating systems. During the winter season, the available solar energy is more than sufficient to meet energy requirements. During the hot season, however, the intense solar radiation and the high air temperatures are problematic. Different active and passive strategies are, therefore, used to counteract this excessive energy intake with a considerable increase in costs. We believe that using this surplus energy to produce electricity would: i) provide an income from the sale of electricity; ii) allow the greenhouse to be used throughout the year; iii) reduce the costs of cooling the greenhouse. This paper aims to identify the energy surplus in relation to cultivation requirements that could be used to produce electricity with new and innovative solutions based on flexible and semi-transparent photovoltaic modules. The research was carried out with reference to the southern coast of the Lazio region, central Italy, by evaluating energy supply and demand to determine the surplus of solar energy produced in a greenhouse covered with double plastic film. Besides the shape of the greenhouse, the surplus depends on the covering material and the location. The degree of cloud cover and the type of cultivation carried out in the greenhouse also have an impact. We calculated the surplus energy under extreme conditions: clear sky and cloudy sky, and according to different crop species (tomato 12 months, tomato 8 months, aubergine 12 months).
\end{abstract}

Correspondence: Alvaro Marucci, Department of Agriculture, Forests, Nature and Energy (D.A.F.N.E.), University of Tuscia, via S. Camillo de Lellis, snc 01100, Viterbo, Italy.

Tel. +39.761 .357365 - Fax: +39.761 .357453$

E-mail: marucci@unitus.it

Key words: Mediterranean greenhouse, photovoltaic system, solar energy.

Received for publication: 9 November 2012.

Accepted for publication: 3 March 2013.

(C) Copyright A. Marucci et al., 2013

Licensee PAGEPress, Italy

Journal of Agricultural Engineering 2013; XLIV:e1

doi:10.4081/jae.2013.e1

This article is distributed under the terms of the Creative Commons Attribution Noncommercial License (by-nc 3.0) which permits any noncommercial use, distribution, and reproduction in any medium, provided the original author(s) and source are credited.
Results showed: i) the surplus of energy available in the greenhouse for the production of energy from new generation solar cells with varying degrees of sky coverage and crop species; ii) the times of the year in which there is an effective surplus of energy; iii) the most suitable crop cycles to achieve a surplus of solar energy to be exploited in the most convenient way.

\section{Introduction}

The spectral distribution of solar radiation at the earth's surface must be taken into account as a weighting function to calculate radiometric coefficients of covering materials. Approximately $50 \%$ of the total energy is emitted in the near infrared radiation range (700-2500 $\mathrm{nm}$ ) and nearly $40 \%$ in the photosynthetically active radiation (PAR) range $(400-700 \mathrm{~nm})$, where the solar radiation has a maximum at a wavelength of approximately $500 \mathrm{~nm}$ (Duffie and Beckman, 1991).

In spectral analysis some wavelengths are more important than others. Variations of blue (B, 400-500 nm), red (R, 650-670 nm) and farred (FR, 720-740 $\mathrm{nm}$ ) radiation in the protected environment affect plant photomorphogenesis. In fact, the phytochrome response is characterised in terms of the R to FR ratio (Smith, 1982; Murakami, 1996; Kittas and Baille, 1998; Kittas et al., 1999; Takaichi et al., 2000; OrenShamir et al., 2001).

The production of energy from renewable sources, the diversification of the production activities, and the development of photovoltaic technology and integrated systems have led to the development of solar greenhouses (Carlini et al., 2012).

For some years, particular interest has been shown in the design and set up of small and medium sized installations for the production of electricity from renewable sources, and this has been encouraged by significant government incentives.

The use of photovoltaic panels has attracted attention because they are appropriate in a range of different situations and enjoy the benefits of significant public incentives according to crop species and cultivation objectives.

In particular, greater funding is available if the panels are installed on agricultural constructions for crop production.

The greenhouse represents one of the most interesting possibilities for installing these panels on agricultural constructions because it is designed to make the best use of solar radiation and usually has a large surface area to accommodate the photovoltaic panels on the roofs.

Moreover, in some periods of the year, especially in southern Italy, the solar radiation that affects the greenhouses is excessive in relation to requirements, and this is sufficient to have to resort to passive (shading nets, thermal screens, etc.) or dynamic (natural or forced ventilation, fogging, or evaporation of water, etc.) means of protection or the agricultural activity has to be suspended (Marucci and Boccia, 1994; Scarascia Mugnozza, 1999; Gusman and Marucci, 2001; Marucci, 
2006; Vox et al., 2010). This has led to us to explore ways to exploit this surplus of solar energy to produce electrical energy that can be used in various ways, e.g. for cooling systems and/or for direct sale to the distribution companies, etc.

The fundamental problem is that traditional silicon-based photovoltaic panels are not transparent so, once installed, they impede solar radiation from penetrating inside the greenhouse. This creates problems for plant cultivation of plants and creates the greenhouse effect.

Partially transparent technological materials are currently being developing. These are made of film or semi-rigid panels that allow a certain proportion of solar energy to pass through.

In our opinoin, to test whether this technology can be widely applied to Mediterranean greenhouses, the following questions must be answered: i) how much solar energy can be used for the production of electrical energy without compromising plant cultivation in the greenhouse? ii) for how many months a year is there a useful and efficient surplus of solar power? iii) what crops and crop cycles provide the largest surplus of solar energy to be used for the production of electrical energy? iv) are the climatic conditions in Italy suitable for the production of photovoltaic electric energy using the excess of solar radiation in the greenhouse without compromising the harvest?

To try to answer these questions, we studied the climatic conditions of Borgo San Michele, in the province of Latina (LT) in the Agro Pontino in central Italy, an area with a strong vocation for greenhouse crops (Figure 1).

\section{Materials and methods}

The research was conducted with reference to a greenhouse for horticultural crops located in the countryside in the province of Latina, central Italy.

First, we analysed climatic conditions using data (temperature and relative humidity, solar radiation and sunshine duration) from the agro-meteorological station of the National Agrometeological Network of Borgo San Michele, Latina (altitude $12 \mathrm{~m}$, latitude $42^{\circ} 27^{\prime} \mathrm{N}$, longitude $12^{\circ} 54^{\prime} \mathrm{E}$ ).

We then studied a greenhouse typical to this area with the following characteristics (Figure 2):

- length $50 \mathrm{~m}$;

- width $12 \mathrm{~m}$;

- height of eaves $3.5 \mathrm{~m}$;

- roof flap slope $40 \%\left(22^{\circ}\right)$;

- cover material: double plastic film polyethylene - ethylenevinylacetate (EVA);

- thickness of film $0.18 \mathrm{~mm}$;

- transmissivity in the PAR range $(400-700 \mathrm{~nm})$ : polyethylene $=0.80$, $\mathrm{EVA}=0.82$;

- transmissivity in the longwave infrared range (7500-12,500 nm): polyethylene=0.60, EVA=0.45.

For this greenhouse, we evaluated energy supply and demand for the following crops: i) tomato - annual cycle - transplantation in January; ii) tomato - autumn-spring cycle - transplantation in October and harvesting in April; iii) aubergine - two semi-annual cycles - transplantation in January and July.

We also established the following thermal limitations: i) tomato: 190 days $\left(\mathrm{t}_{\text {night }}=13^{\circ} \mathrm{C} ; \mathrm{T}_{\text {day }}=17^{\circ}\right),>90$ days $\left(\mathrm{t}_{\text {night }}=15^{\circ} \mathrm{C} ; \mathrm{T}_{\text {day }}=24^{\circ}\right) ;$ ii $)$ aubergine: throughout the study period $\left(\mathrm{t}_{\text {night }}=13^{\circ} \mathrm{C} ; \mathrm{T}_{\text {day }}=25^{\circ}\right)$.

Using these parameters, we evaluated energy supply and demand for each average day of each month at time intervals of $15 \mathrm{~min}$ and under the following conditions: i) clear sky (direct and diffuse radiation); ii) cloudy sky (diffuse radiation); iii) night.

\section{Energy supply and demand}

As mentioned above, the energy supply and demand was evaluated for the greenhouse for selected crops by adopting the thermal regimes specified. This included the energy loss through transmission and irradiation of the crop toward the cover and the sky, and losses, again through irradiation, from the roof to the sky, and the solar energy available in the greenhouse. This analysis did not take into account energy losses due to ventilation, because the aim of the study was to quantify the surplus of solar energy available after subtracting losses due to the physical characteristics of the transparent cover materials. As we know, the main function of natural or forced ventilation is to try to expel this surplus thermal energy of solar origin outside the greenhouse.

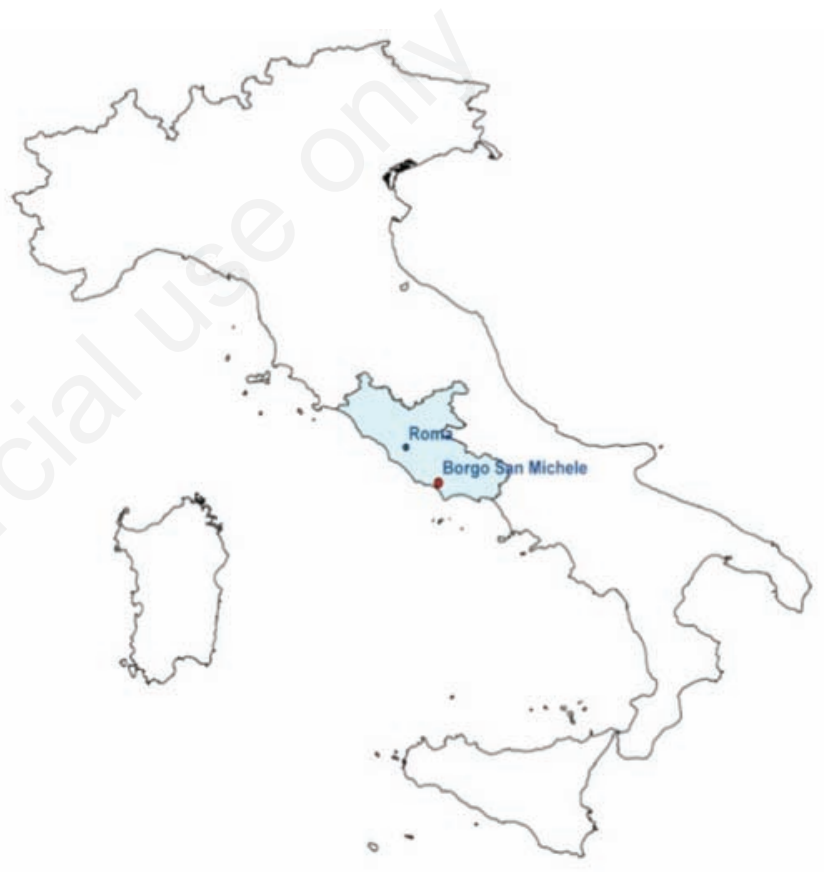

Figure 1. Borgo San Michele (Latina).

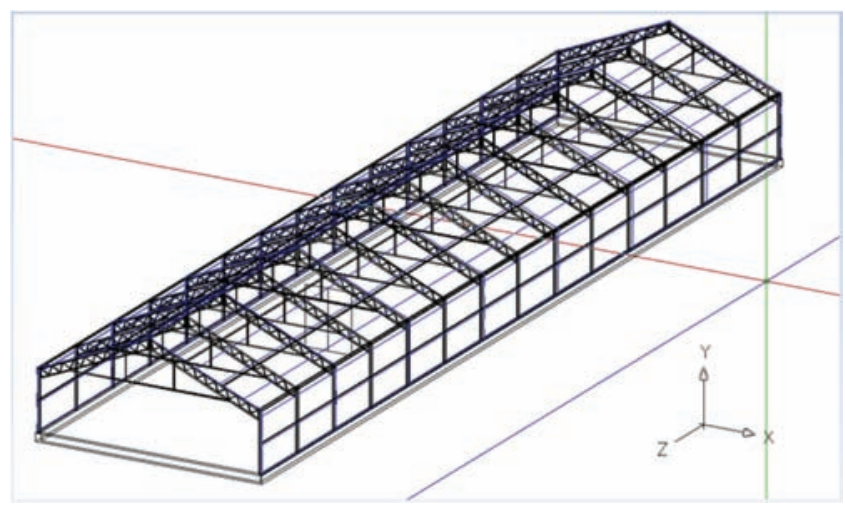

Figure 2. Typical greenhouse structure for horticultural crops in the Agro Pontino area. 
The energy supply and demand per unit area (Campiglia, 2007; Marucci 2011a, 2011b; Figure 3) for Mediterranean greenhouse is as follows:

$$
\begin{aligned}
& R_{i}+R_{a c}=R T_{g, s k y}+R T_{g, a t m}+R T_{p, s k y}+R T_{p, a t m}+R T_{c, s k y}+R T_{g, a t m} \\
& +E_{T}+E_{V}+\Delta E_{g}+S_{g}
\end{aligned}
$$

where:

$$
E_{T}=K S\left(T_{i}-T_{e}\right)
$$

$\mathrm{K}$ is thermal transmittance $\left(\mathrm{W} \mathrm{m}^{-2} \mathrm{~K}^{-1}\right)$;

$\mathrm{S}$ is wall surface $\left(\mathrm{m}^{2}\right)$;

$\mathrm{T}_{\mathrm{i}}$ is internal temperature $\left({ }^{\circ} \mathrm{C}\right)$;

$\mathrm{T}_{\mathrm{e}}$ is external temperature $\left({ }^{\circ} \mathrm{C}\right)$.

$$
\mathrm{E}_{\mathrm{v}}=\left(\mathrm{H}_{\mathrm{i}}-\mathrm{H}_{\mathrm{e}}\right)
$$

$\mathrm{E}_{\mathrm{v}}$ is energy lost through ventilation $\left(\mathrm{kJ} \mathrm{h}^{-1}\right)$;

$\mathrm{V}$ is flow rate of ventilation (kgDryAir $\mathrm{h}^{-1}$ );

$\mathrm{H}_{\mathrm{i}}$ is internal air enthalpy ( $\left.\mathrm{kJ} \mathrm{kgDryAir}^{-1}\right)$;

$\mathrm{H}_{\mathrm{e}}$ is external air enthalpy ( $\left.\mathrm{kJ} \mathrm{kgDryAir}^{-1}\right)$.

The enthalpy ( $\left.\mathrm{kJ} \mathrm{kgDryAir}{ }^{-1}\right)$ of a $\mathrm{kg}$ of air, at temperature $\mathrm{t}\left({ }^{\circ} \mathrm{C}\right)$ and with water content, in the form of water, equal to $\times\left(\mathrm{kg} \mathrm{kgDryAir}^{-1}\right)$ is obtained from:
$\mathrm{H}=1.005 \mathrm{t}+\times(2499.5+2.005 \mathrm{t})$

$\times\left(\mathrm{kg} \mathrm{kgDryAir}^{-1}\right)$ represents the water vapor contained in the air and can be determined through the psychrometric diagram or with the following formula:

$$
\mathrm{x}=0.6215 \frac{\mathrm{p}_{\mathrm{H}_{2} \mathrm{O}}}{\mathrm{p}-\mathrm{p}_{\mathrm{H}_{2} \mathrm{O}}}
$$

p is $1.013\left(\mathrm{~kg} \mathrm{~cm}^{-2}\right)$ atmospheric pressure;

$\mathrm{p}_{\mathrm{H} 20}$ is vapor pressure of the air, expressed in $\mathrm{kg} \mathrm{cm}^{-2}$ at temperature T (K) and at relative humidity UR (\%).

$$
\mathrm{P}_{\mathrm{H}_{2} \mathrm{O}}=1.41 \times 10^{10} \mathrm{e}^{\left(\frac{-3928.5}{\mathrm{~T}-41.5}\right)} \times \mathrm{UR}
$$

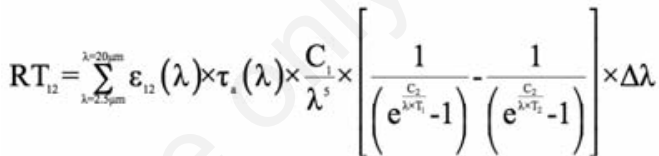

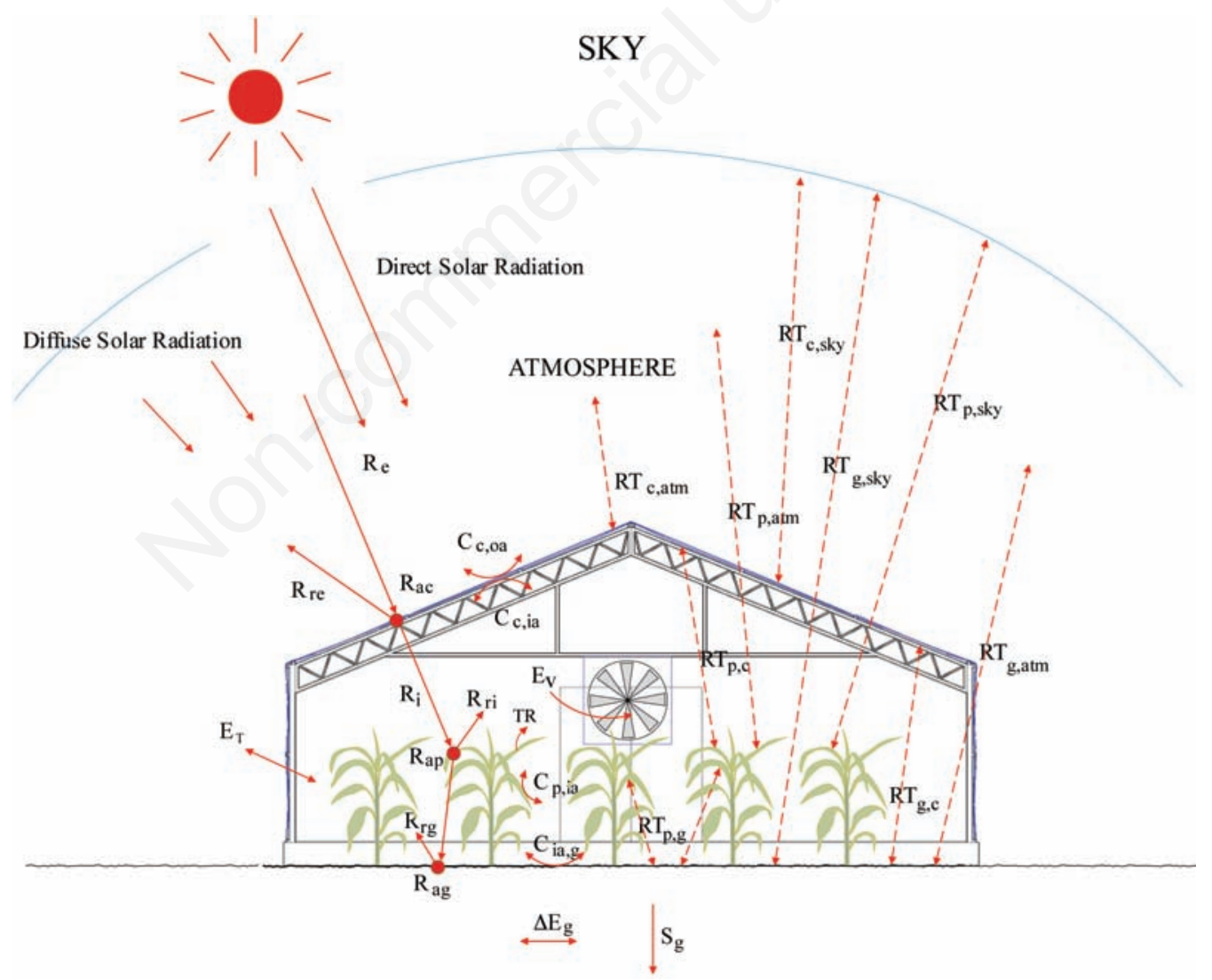

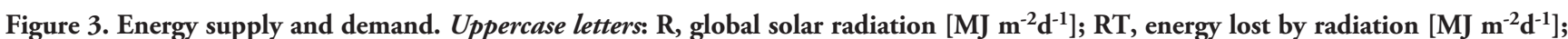
$\mathrm{C}$, energy exchanged by convection $\left[\mathrm{MJ} \mathrm{m}^{-2} \mathrm{~d}^{-1}\right]$; ET, energy lost by transmission $\left[\mathrm{MJ} \mathrm{m}^{-2} \mathrm{~d}^{-1}\right] ; \mathrm{EV}$, energy lost by ventilation $\left[\mathrm{MJ} \mathrm{m}^{-2} \mathrm{~d}^{-1}\right]$; TR, plant transpiration $\left[\mathrm{MJ} \mathrm{m}^{-2} \mathrm{~d}^{-1}\right] ; S$, energy transferred by conduction in the deep layers $\left[\mathrm{MJ} \mathrm{m}^{-2} \mathrm{~d}^{-1}\right]$; E, thermal storage $\left[\mathrm{MJ} \mathrm{m}^{-2} \mathrm{~d}^{-1}\right]$. Lowercase letters: e, external; re, reflected external; ac, absorbed by the cover; i, internal; ri, reflected internal; ap, absorbed by the plants; rg, reflected from the ground; ag, absorbed by the soil; c, covering film; p, plants; g, ground; ia, indoor air; oa, outdoor air; atm, atmosphere; sky, vault of heaven. 
$\mathrm{RT}_{12}$ is radiated radiation $\left(\mathrm{W} \mathrm{m}{ }^{-2}\right)$;

$\lambda$ is wavelength $(\mathrm{m})$;

$\mathrm{T}$ is absolute temperature $(\mathrm{K})$;

$\mathrm{C}_{1}$ is $3.74 \times 10^{8}\left(\mathrm{~W} \mathrm{~m}^{4} \mathrm{~m}^{-2}\right)$;

$\mathrm{C}_{2}$ is $14385(\mathrm{~K} \times \mathrm{m})$;

$\tau_{\mathrm{a}(\mathrm{I})}$ is transmittance of the atmosphere at the wavelength $\mathrm{l}$;

$\varepsilon_{(\lambda)}$ is monochromatic emissivity of the object at the wavelength l.

\section{Results and discussion}

Results of statistical analysis of climatic data collected at the station of Borgo San Michele from 2001 to 2010 by the Central Bureau of Agricultural Ecology (UCEA) of the Italian Ministry of Agriculture and Forestry are shown in Table 1. In our opinion, one of the most important climatic elements for evaluating the potential of a location to host a greenhouse production facility is the average number of hours per day when there is direct solar radiation (daily average sunshine duration) as this indicates the quality and quantity of sunlight that is available.

In the location under study, analysis showed that the average duration of sunshine measured per day increased from a minimum $35-40 \%$ of the total theoretical length of days in the winter months to a maximum $72-73 \%$ in summer (Figure 4).

The theoretical length of the day was calculated using the equation:

$$
N_{o}=\frac{2}{15} \cdot \operatorname{arcos}(-\operatorname{tg} \phi \cdot \operatorname{tg} \delta)
$$

where:

$\mathrm{N}_{0}$ is length of day (max. number hours of sunshine) [h];

$F$ is latitude $\left[{ }^{\circ}\right]$;

$d$ is declination of the sun $\left[{ }^{\circ}\right]$.

From April to October, however, the average hours of daily sunshine exceeds $50 \%$ of the theoretical length of the day. This is a very important feature of the site because it helps to have a range of at least 1012 days of clear skies in the winter months up to over 20 days in the warmer months. This is confirmed by the comparison between the measured and calculated solar radiation (Figure 5). The calculated solar radiation was obtained by the method according to Liu and Jordan

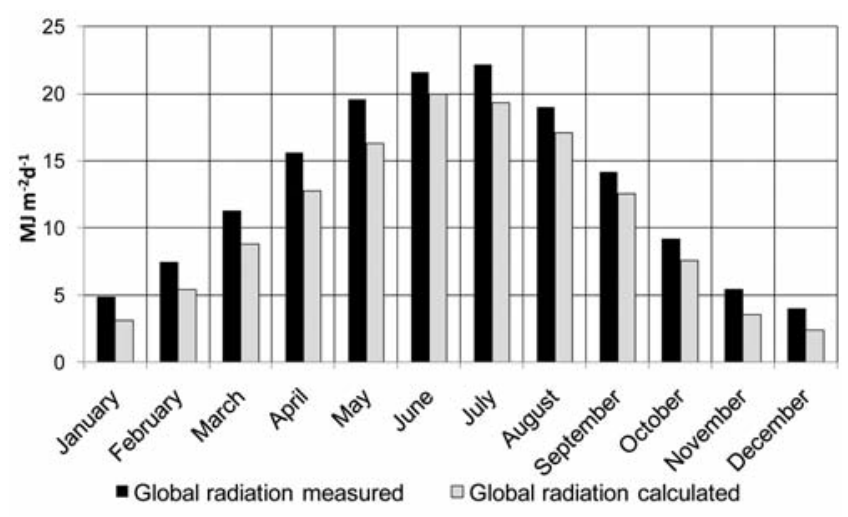

Figure 4. Comparison between theoretical length of the day and sunshine duration measured.

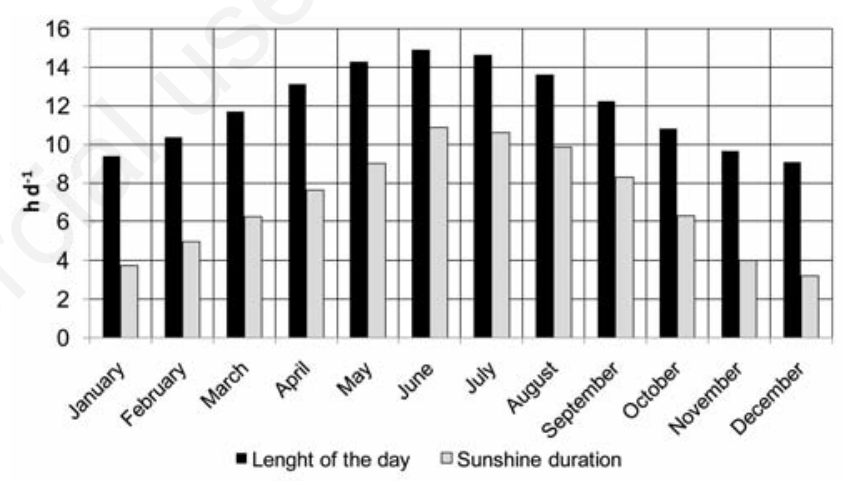

Figure 5. Comparison between the calculated and measured solar radiation in Borgo San Michele.

Table 1. Monthly mean values of climatic parameters measured at Borgo San Michele (Central Bureau of Agricultural Ecology).

\begin{tabular}{|c|c|c|c|c|c|}
\hline Month & ${ }^{\mathrm{T}} \min ^{\circ} \mathrm{C}$ & ${ }^{\mathrm{T}} \max$ & RH (mean) & $\begin{array}{l}\text { Sunshine duration } \\
\mathrm{h} / \mathrm{d}\end{array}$ & $\begin{array}{c}\text { Solar radiation } \\
\mathrm{MJ} / \mathrm{m}^{2} \mathrm{~d}\end{array}$ \\
\hline 1 & 2.7 & 13.1 & 77.2 & 3.8 & 4.8 \\
\hline 2 & 3.0 & 13.9 & 75.3 & 4.9 & 7.4 \\
\hline 3 & 4.9 & 16.3 & 77.9 & 6.3 & 11.3 \\
\hline 4 & 7.7 & 19.6 & 78.2 & 7.6 & 15.6 \\
\hline 5 & 11.1 & 24.2 & 74.1 & 9.0 & 19.6 \\
\hline 6 & 14.8 & 28.1 & 72.1 & 10.9 & 21.6 \\
\hline 7 & 16.8 & 30.6 & 68.8 & 10.6 & 22.2 \\
\hline 8 & 17.0 & 30.5 & 70.4 & 9.9 & 19.0 \\
\hline 9 & 13.8 & 26.7 & 73.8 & 8.3 & 14.1 \\
\hline 10 & 11.4 & 23.3 & 80.9 & 6.3 & 9.2 \\
\hline 11 & 7.6 & 18.4 & 80.1 & 4.0 & 5.5 \\
\hline 12 & 4.4 & 14.4 & 76.6 & 3.2 & 4.0 \\
\hline
\end{tabular}

RH, relative humidity; $\mathrm{h} / \mathrm{d}$, hour per day. 


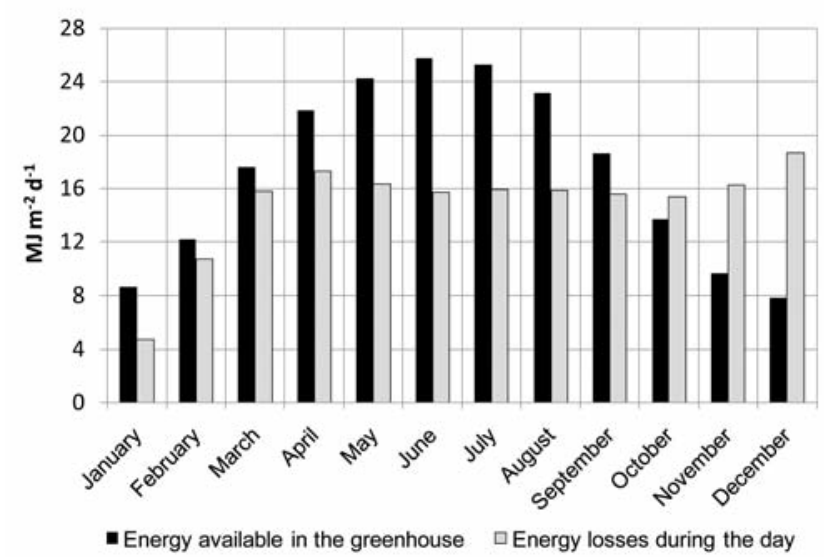

Figure 6. Comparison of energy supply and demand on clear days.

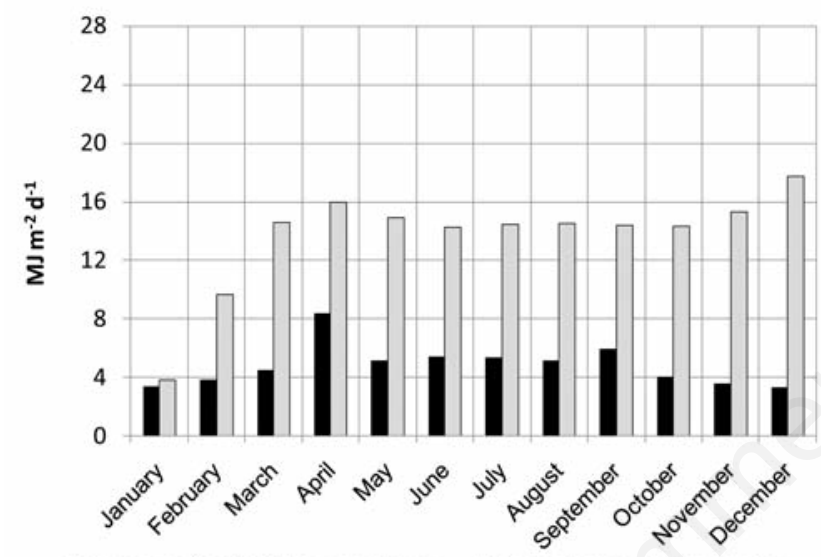

- Energy available in the greenhouse $\square$ Energy losses during the day

Figure 7. Comparison of energy supply and demand on cloudy days.

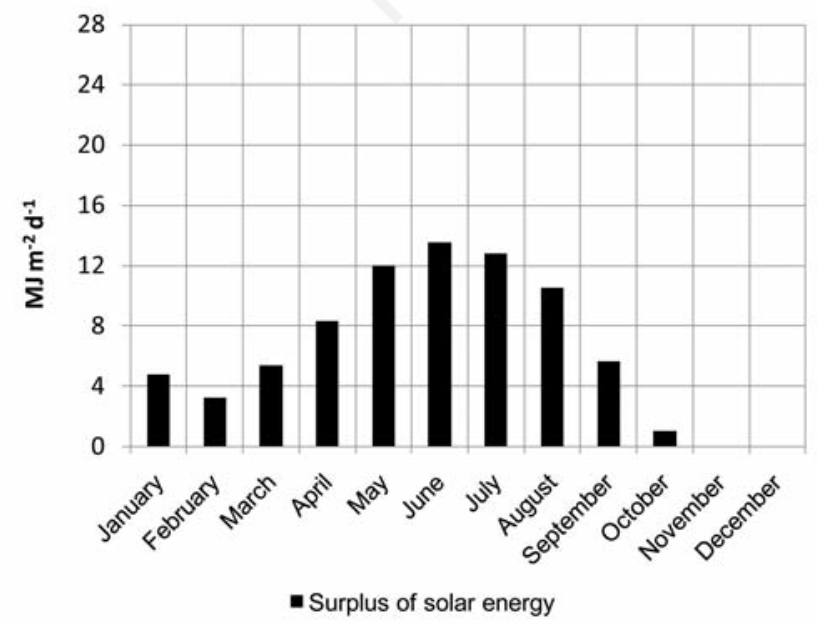

Figure 8. Surplus of solar energy on clear days.

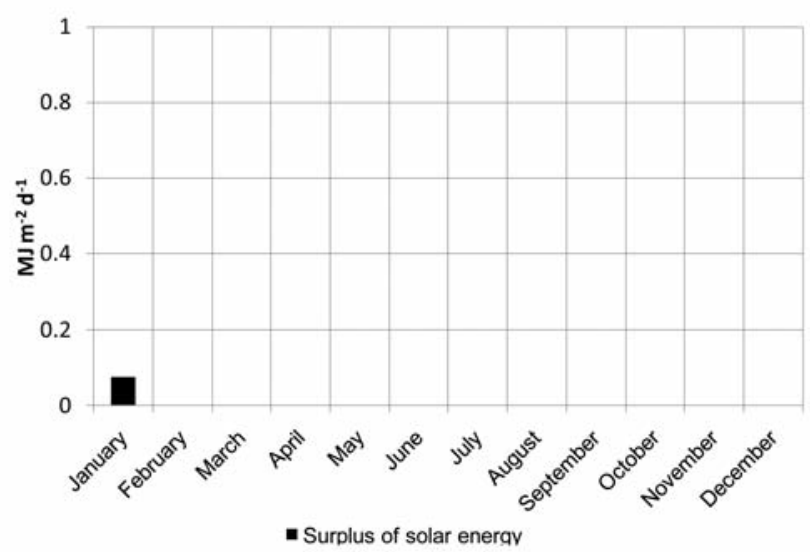

Figure 9. Surplus of solar energy on cloudy days.

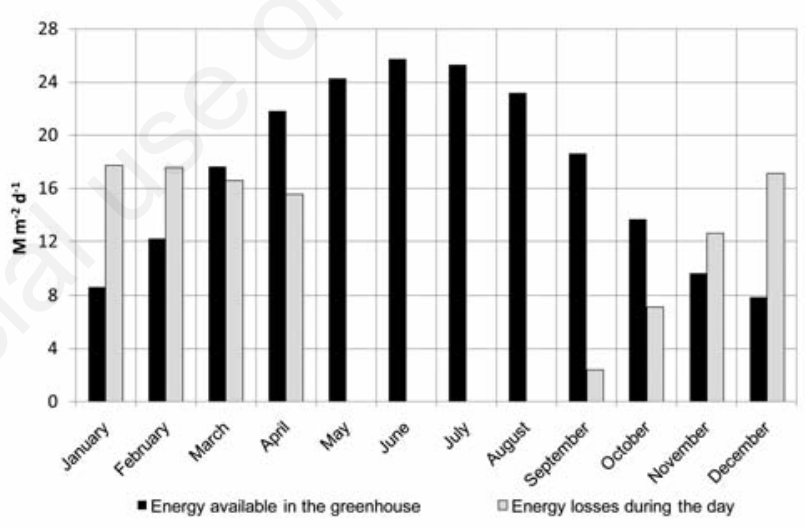

Figure 10. Comparison of energy supply and demand on clear days.

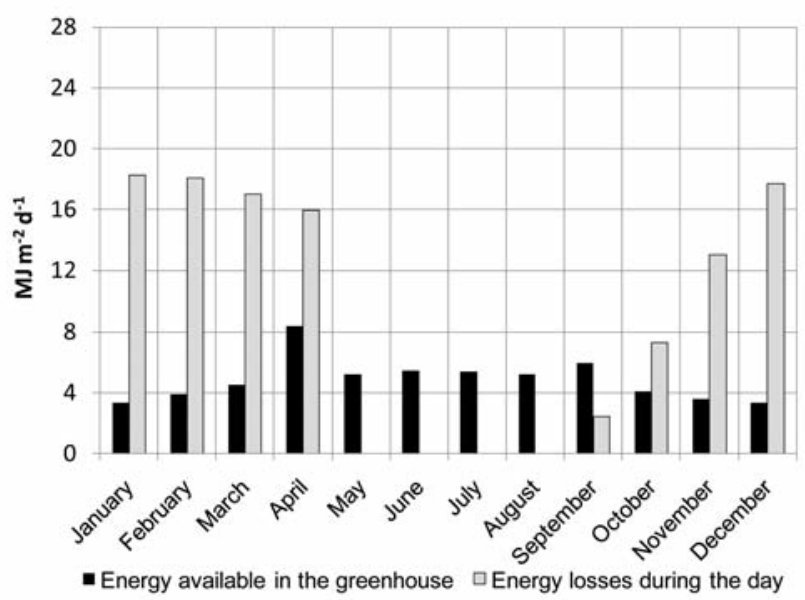

Figure 11. Comparison of energy supply and demand on cloudy days. 


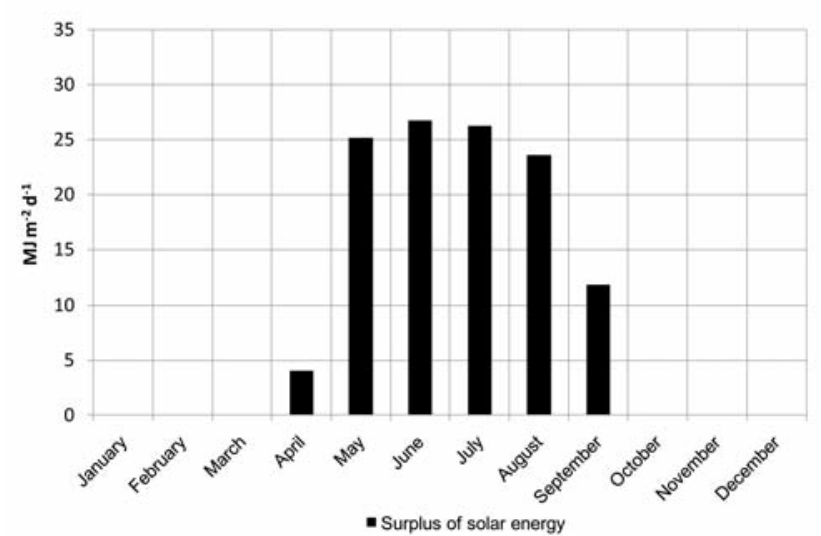

Figure 12. Surplus of solar energy on clear days.

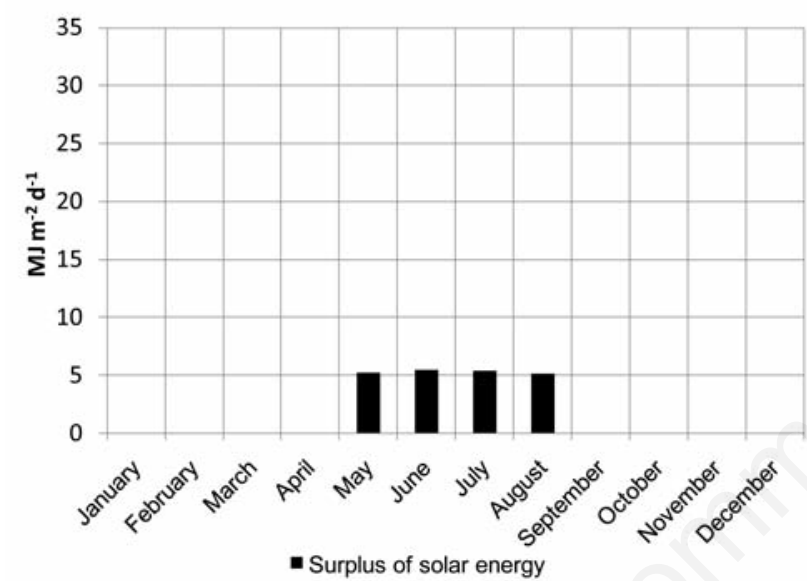

Figure 13. Surplus of solar energy on cloudy days.

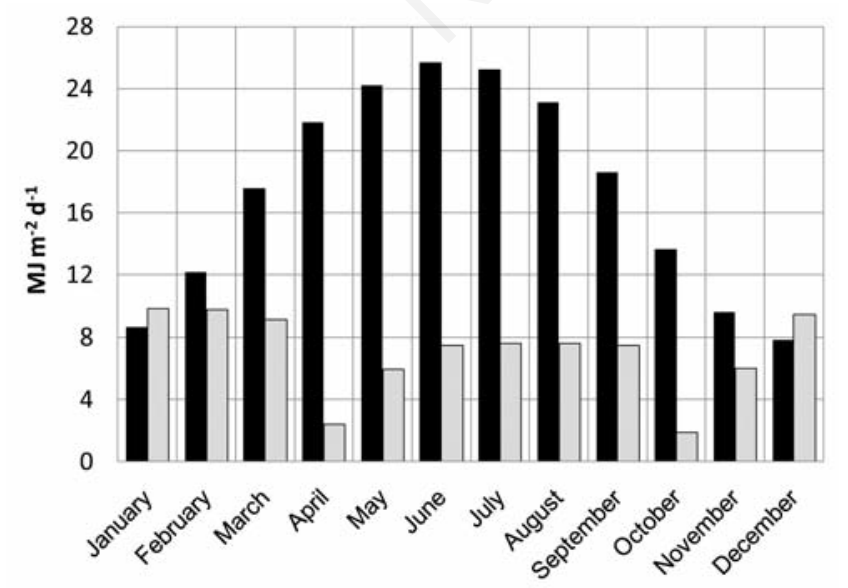

- Energy available in the greenhouse $\square$ energy losses during the day

Figure 14. Comparison of energy supply and demand on clear days.

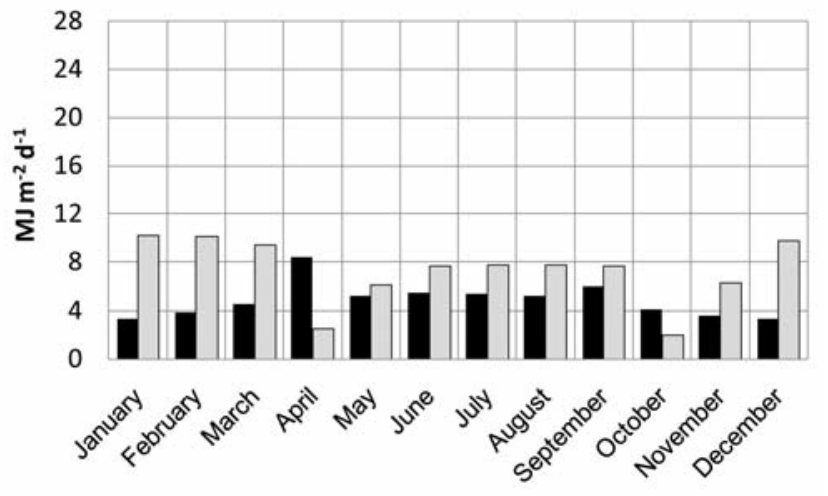

- Energy available inthe greenhouse $\square$ Energy losses during the day

Figure 15. Comparison of energy supply and demand on cloudy days.

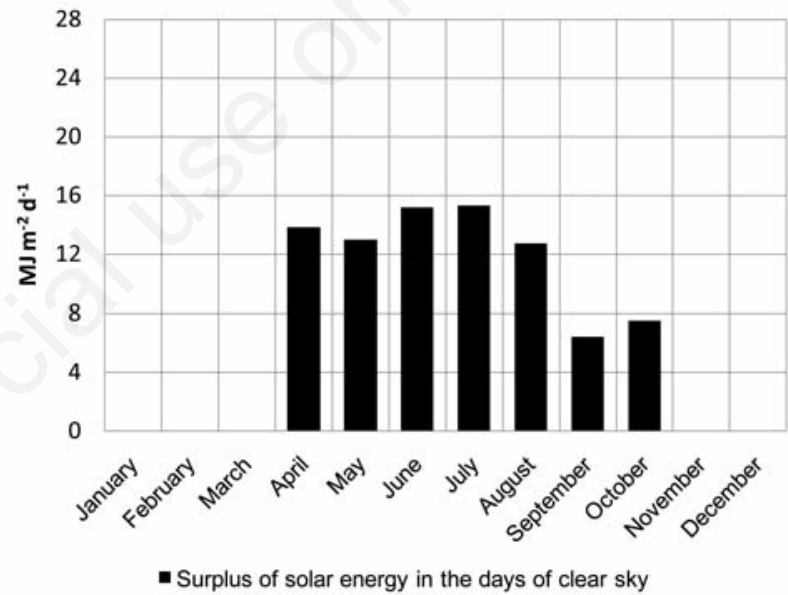

Figure 16. Surplus of solar energy on clear days.

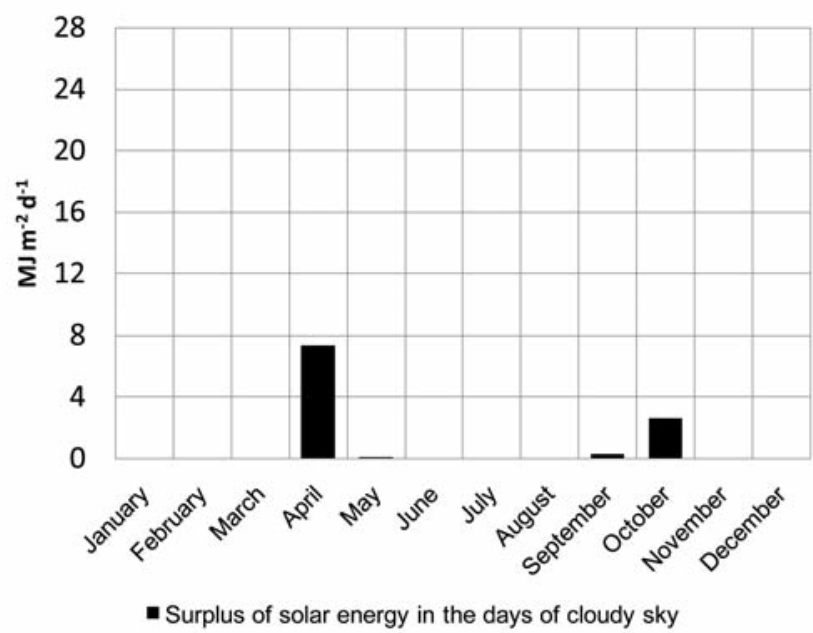

Figure 17. Surplus of solar energy on cloudy days. 
(1960) that showed a reasonable correspondence between the two values, with differences in the order of $6 \%$.

In other terms, the state of the sky in this position, even when there is no direct solar radiation, is such as to let through a higher amount of solar energy, albeit slightly, compared to that estimated.

\section{Tomato: annual crop (12 months)}

Taking into account the thermal limitations required by the crop in different phenological phases, we considered the periods of clear and cloudy sky. Results are shown in Figures 6 and 7.

Figure 8 shows the surplus of solar energy produced on the outside roof of the greenhouse at different times of the year, on clear sky days, when the tomato is grown throughout the year and transplanted in January.

As expected, the most significant surplus of solar energy occurs in the summer months, from May to August, with values ranging between $8 \mathrm{MJ} \mathrm{m}^{-2} \mathrm{~d}^{-1}$ and $11 \mathrm{MJ} \mathrm{m}^{-2} \mathrm{~d}^{-1}$.

Once it has penetrated inside, this energy, albeit reduced due to the transmittance of the cover, can be eliminated through ventilation and/or cooling systems with air, especially during the summer months.

It would also be possible to prevent the excess energy penetrating inside the covering. In other months, always on clear sky days, either

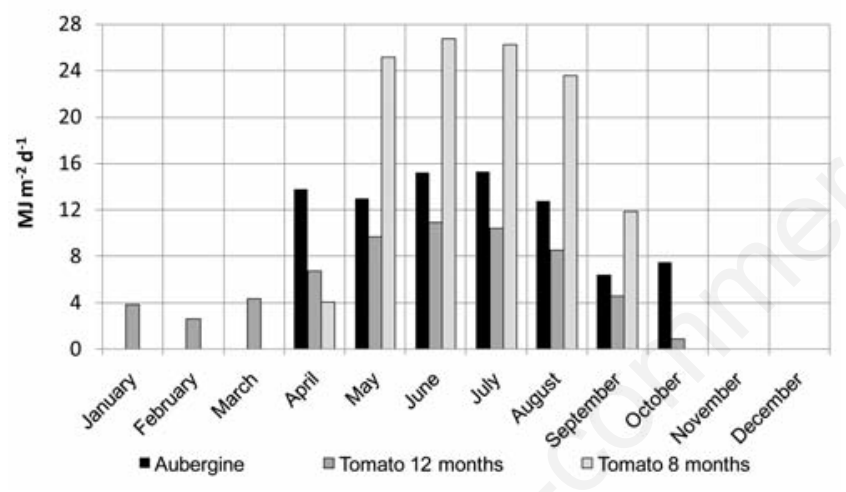

Figure 18. Surplus of energy on clear days.

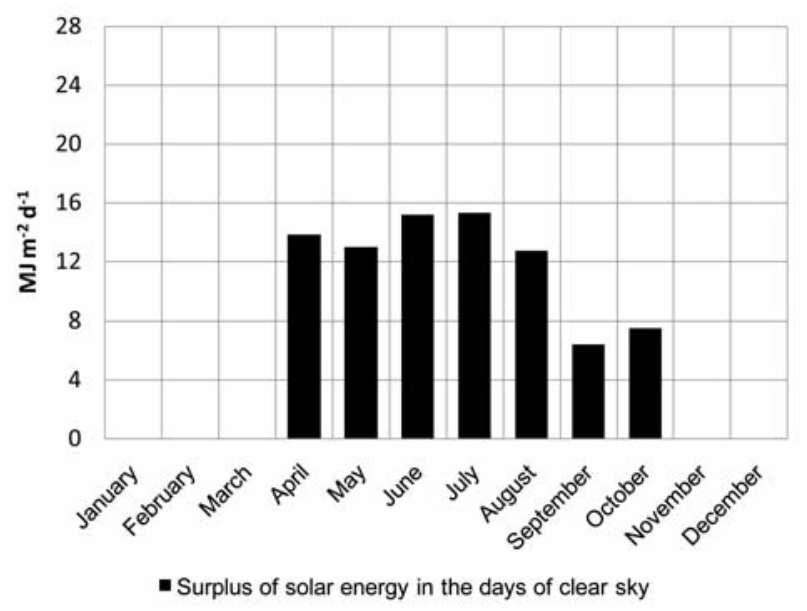

Figure 19. Surplus of energy on cloudy days. there is no surplus (October, November and December) or the surplus is, in our opinion, insignificant, and could in practice be easily regulated with a ventilation system.

On the days of cloudy skies and no direct sunlight, there is no surplus except for a small amount in the month of January due to lower thermal requirements of the newly transplanted seedlings (Figure 9).

\section{Tomato: autumn-spring crop (8 months)}

If, for example, the tomato cultivation is limited to the period from September to April (i.e. crop transplanted in September and harvested in April), leaving the greenhouse unused in the summer, the surplus of solar energy is as shown in Figures 10 and 11.

Clearly, not using the greenhouse in summer, all the solar energy that reaches the greenhouse becomes available, even on overcast days.

For the purpose of conversion into electrical energy by the photovoltaic process, as in the previous case, only the rate that affects the pitch of coverage can be conveniently used for this purpose (Figures 12 and 13).

\section{Aubergine: two semi-annual cycles}

Then another evaluation was performed by replacing the aubergine to the tomato crop, grown throughout the year with two crop cycles (transplanted in April and October). The results of the processing performed are shown in Figures 14 and 15.

With aubergine cultivation, on clear days, the surplus of solar energy is much greater (13-15 $\mathrm{MJ} \mathrm{m}^{-2} \mathrm{~d}^{-1}$ ) than that produced with tomato (8$11 \mathrm{MJ} \mathrm{m}^{-2} \mathrm{~d}^{-1}$ ) (Figures 16 and 17). On days with overcast skies, a surplus is only produced in two months and amounts are less significant.

The analysis showed that on the cover, outside the greenhouse, with crops under cultivation (aubergines), daily averages can peak at approximately $15 \mathrm{MJ} \mathrm{m}^{-2} \mathrm{~s}^{-1}$ (Figure 18). These peaks remain almost constant throughout the summer on clear days.

On cloudy days, these peaks are significantly reduced; down to approximately $5 \mathrm{MJ} \mathrm{m}^{-2} \mathrm{~d}^{-1}$ (Figure 19), just for the summer months and in the absence of crops.

In other months, there is a modest (approx. $2.5 \mathrm{MJ} \mathrm{m}^{-2} \mathrm{~d}^{-1}$ ) surplus during the months of April and October at transplantation of aubergine (two semi-annual cycles).

In the area under study, in the summer months, over $70 \%$ of the days can be considered fine. This means that, if we want to, we have just over four months per year available for transforming solar energy into photovoltaic energy.

\section{Conclusions}

This research, carried out in an area with a strong commitment to greenhouse crops such as the Agro Pontino area, has provided useful information about the possible use of Mediterranean greenhouses, in widespread use for vegetable production, to support photovoltaic covers. These are the first findings available regarding the availability of surplus solar energy for conversion into electrical energy.

Actually, it was found that, not only in summer but also at other times of the year, there may be some excess solar energy inside the greenhouse that forces the farmer to use indoor climate control systems to prevent damage to crops. These systems often become demanding and complex because high air temperature is combined with very high solar radiation.

The data obtained highlight the need to programme cultivation of crops and their cycles correctly in order to exploit the available solar 
energy not only for crops but also for conversion into electrical energy.

Growing tomatoes all year round or restricting cultivation to only eight months of autumn, winter and spring, produces a very different energy surplus, in a ratio of approximately 1:2.5.

However, tomato cultivation for eight months instead of 12 reduces production and, therefore, results in a lower income from the product.

A correct economic evaluation should be made to compare the lower income from agricultural production and lower costs for internal climate control with the proceeds from the sale of the electricity produced. If such proceeds can compensate for the lower income from agricultural production, then using the greenhouse frame to support a photovoltaic system could be a serious proposition.

However, another problem must to be solved: how can we cover the roof quickly when there is a surplus availability of solar energy? While it is not difficult to predict in advance when cover the roof, put promptly the semitransparent photovoltaic film on the cover is not technically easy.

We believe that rigid and opaque panels (e.g. common silicon panels) are to be excluded. The solution may be found in the use of flexible and semi-transparent photovoltaic sheets. Their flexibility means they can be coiled and, therefore, could be rolled out quite easily during the day as if they were shading nets when there is surplus energy available. These sheets are also semi-transparent and this ensures that inside the greenhouse a suitable rate of solar radiation is reached to meet plant requirements and to create the greenhouse effect.

Current technology is being used to develop materials like these although, for the moment, their conversion efficiency of solar energy into electricity is not very high (only 5-8\%).

However, much research is ongoing in this area so there is every hope that more efficient photovoltaic sheets will be developed to combine the use of greenhouses for agricultural production and the production of electricity using photovoltaic cells.

\section{References}

Campiglia E., Colla G., Mancinelli R., Rouphael Y., Marucci A. 2007. Energy balance of intensive vegetable cropping systems in central Italy. Acta Horticul. 747:185-91.

Carlini M., Honorati T., Castellucci S. 2012. Photovoltaic greenhouses: comparison of optical and thermal behaviour for energy savings. Math. Probl. Engine. 2012:743764.

Duffie J.A., Beckman W.A. 1991. Solar engineering of thermal processes. John Wiley \& Sons, New York, NY, USA.

Gusman A., Marucci A. 2001. La radiazione solare all'interno di tunnel coperti con film plastico. Atti Convegno AIIA "Ingegneria Agraria per lo sviluppo dei paesi del mediterraneo", September 11-14, Vieste (Fg), Italy.

Kittas C., Baille A. 1998. Determination of the spectral properties of several greenhouse cover materials and evaluation of specific parameters related to plant response. J. Agricult. Engine. Res. 71:193-202.

Kittas C., Baille A., Giaglaras P. 1999. Influence of covering material and shading on the spectral distribution of light in greenhouses. J. Agricult. Engine. Res. 73:341-51.

Liu B.Y.H., Jordan R.C. 1960. The interrelationship and characteristic distribution of direct, diffuse and total solar radiation. Sol. Ener. $4: 1$.

Marucci A. 2006. Materiali di copertura per tunnel e serre. Informatore Agrario 33:62-79.

Marucci A., Boccia L. 1994. Relationship between solar radiation and covering materials in protected cropping structures. Atti del XII CIGR World Congress and AGEng '94 Conference on Agricultural Engineering, August 29-September 1, Milano, Italy.

Marucci A., Campiglia E., Colla G., Pagniello B. 2011a. Environmental impact of fertilization and pesticide application in vegetable cropping systems under greenhouse and open field conditions. J. Food Agricult. Environ. 9:840-6.

Marucci A., Pagniello B. 2011b. Simulation of the growth and the production of the tomato in typical greenhouses of the Mediterranean environment. J. Food Agricult. Environ. 9:407-11.

Murakami K., Cui H., Kiyota M., Takemura Y., Oi R., Aiga I. 1996. Covering materials to control plant growth by modifying the spectral balance of daylight. Plasticulture. 110:2-14.

Oren-Shamir M., Gussakovsky E.E., Shpiegel E., Nissim-Levi A., Ratne K., Ovadia R., Giller Y.E., Shahak Y. 2001. Coloured shade nets can improve the yield and quality of green decorative branches of Pittosporum variegatum. J. Horticul. Sci. Biotechnol. 76:353-61.

Scarascia Mugnozza G. 1999. Aspetti strutturali e impiantistici degli apprestamenti per le colture protette: criteri attuali e prospettive. Atti del Seminario AIIA "Le colture protette: aspetti agronomici, territoriali e tecnico-costruttivi”, June 24-26, Ragusa, Italy.

Smith H. 1982. Light quality, photoperception, and plant strategy. Ann. Rev. Plant Physiol. 33:481-518.

Takaichi M., Shimaji H., Higashide T. 2000. Effect of red/far-red photon flux ratio of solar radiation on growth of fruit vegetable seedlings. Acta Horticul. 514:147-56.

Vox G., Teitel M., Pardossi A., Minuto A., Tinivella F., Schettini E. 2010. Chapter 1: Sustainable greenhouse systems. In: A. Salazar and I. Rios (eds), Sustainable agriculture: technology, planning and management. Nova Science Publishers, Inc., New York, NY, USA, pp 1-79. 